\title{
BENTUK - BENTUK PARTISIPASI WARGA NEGARA DALAM PELESTARIAN LINGKUNGAN HIDUP BERDASARKAN KONSEP GREEN MORAL DI KABUPATEN BLITAR
}

\author{
M. Syahri \\ Dosen Prodi PKn FKIP Universitas Muhammadiyah Malang \\ email: syahri@yahoo.com
}

\begin{abstract}
ABSTRAK
Penelitian ini bertujuan untuk mengkaji dan menganalisa bagaimana bentuk-bentuk partisipasi dalam pelestarian lingkungan di Kabupaten Blitar. Metodologi menggunakan pendekatan kualitatif. Hasil penelitian menunjukkan Bentuk-bentuk partisipasi Warga Negara dalam pelestarian lingkungan hidup dilakukan melalui kegiatan-kegiatan masyarakat dan dunia pendidikan (monolitik dan integratif). Kompetensi kewarganegaraan diperlukan agar warga Negara dapat berpartisipasi dalam lingkungan hidup dengan pembekalan dimensi/domain knowledge, skill dan disposition tentang lingkungan hidup melalui berbagai kegiatan di masyarakat dan pendidikan. Bentuk penguatan partisipasi warga Negara dalam Pelestarian Lingkungan Hidup dilakukan melalui kegiatan pelatihan bagi masyarakat, sekolah, sosialisasi tentang lingkungan hidup, penguatan peran organisasi-organisasi relawan lingkungan hidup, serta KMDM di SD dan sekolah SMP.Penguatan partisipasi warga negara tentang pelestarian lingkungan hidup berdasar konsep green moral dalam pembangunan berkelanjutan mengacu pada nilai-nilai Pancasila untuk sopan santun, bersih, mencintai lingkungan, dan menjaga lingkungan hidup untuk tercapai kepekaan terhadap lingkungan hidup melalui adaptasi dari hidup modern dengan mempertahankan dan melindungi lingkungan hidup, tujuan yang jelas dari pelestarian lingkungan hidup, integrasi dari nilai-nilai Pancasila dan lingkungan dalam integrasi berbagai macam kegiatan, serta adanya latency dalam sistem yang dibuat masyarakat dan pemerintah.
\end{abstract}

Kata Kunci : partisipasi, warga negara, pelestarian, lingkungan hidup dan green moral

\section{ABSTRACT}

This study aims to examine and analyze how the form - the form of participation in environmental conservation in Blitar. The methodology uses a qualitative approach. The results showed Forms citizen participation in environmental conservation through community activities and education (monolithic and integrative). Competence citizenship necessary for citizens to participate in a live environment with speech dimension / domain knowledge, skills, and disposition of environment through a variety of activities in the community and education. Shape strengthening citizen participation in the Environmental Protection through training activities for the community, school, socialization environment, strengthening the role of voluntary organizations environmentalists and KMDM in elementary and junior high schools. Strengthening citizen participation based on the concept of environmental sustainability green moral sustainable development refers to the values of Pancasila for manners, clean, loving environment, and conserve the environment for environmental sensitivity is achieved through adaptation of modern life by maintaining and protecting the environment, clear goals of environmental protection, integration of the values of Pancasila and the environment in the integration of a wide range of activities, as well as the latency in the system are made public and the government.

Keywords: participation, citizens, conservation, environment and green moral

\section{PENDAHULUAN}

\section{Partisipasi Warga Negara dalam Menjaga Pelestarian Lingkungan Hidup}

Salah satu tujuan Negara Republik Indonesia sebagaimana tercantum dalam Pembukaan Undang-Undang Dasar Negara Republik Indonesia Tahun 1945 adalah mencerdaskan kehidupan bangsa. Upaya untuk mencerdaskan bangsa salah satunya adalah dengan pendidikan. Suatu bangsa kehidupannya akan maju dan sejahtera apabila bangsa tersebut cerdas.

Penyelenggaraan pendidikan tidak dapat dilepaskan dari tujuan pendidikan yang 
hendak dicapai berdasarkan pembangunan nasional yang hakekatnya dilaksanakan oleh bangsa Indonesia meliputi seluruh bidang kehidupan. Salah satu bidang pendidikan yang diajarkan di sekolah adalah mata pelajaran Pendidikan Kewarganegaraan (PKn). Pendidikan Kewarganegaraan (PKn) merupakan salah satu mata pelajaran yang diajarkan mulai dari tingkat SD sampai Perguruan Tinggi. Dalam kenyataannya, PKn sering dikatakan sebagai mata pelajaran yang membosankan, tidak menarik, penuh dengan teori dan sebagainya.

Perspektif mengenai mata pelajaran PKn yang membosankan dapat semakin kuat apabila guru kurang menerapkan pembelajaran yang membangkitkan motivasi belajar siswa sehingga yang terjadi adalah minimnya keterlibatan siswa dalam proses belajar mengajar dan kecerdasan siswa kurang terasah. Apabila dibiarkan maka fungsi pendidikan tidak dapat tercapai.

Partisipasi warga negara dalam menjaga kelestarian lingkungan hidup di dasari karena manusia merupakan bagian dari lingkungan hidup itu sendiri. Kerusakan pada lingkungan hidup pada dasarnya juga merusak pada diri manusia itu sendiri. Prinsip-prinsip deep ecology (Arne Naess dalam Mudhofir, 2010: 197) adalah: (1) Kesejahteraan dan perkembangan manusia dan non manusia di muka bumi memiliki nilai di dalam dirinya sendiri (seperti nilai intrinsic atau nilai inheren). Nilai-nilai tersebut tidak tergantung dari nilai non-manusia untuk tujuan-tujuan manusia; (2) Kekayaan dan keragaman bentuk-bentuk kehidupan berkontribusi pada kesadaran nilai-nilai mereka sendiri dan juga nilai-nilai inherennya (dalam dirinya sendiri); (3) Manusia tak memiliki hak untuk mengurangi kekayaan dan keragamannya kecuali untuk memenuhi kebutuhan pokok saja; (4) Perkembangan hidup dan budaya manusia sepadan dengan pengurangan subtansial populasi manusia. Perkembangan kehidupan non manusia memerlukan pengurangan semacam ini; (5) Intervensi manusia modern atas dunia non manusia terlalu berlebihan, dan kondisi ini makin memburuk; (6) Karena itu, kebijakankebijakan harus berubah. Kebijakankebijakan tersebut mempengaruhi struktur dasar ekonomi, teknologi, dan juga ideologi. Keadaan yang dihasilkannya akan berbeda dari keadaannya semula; (7) Perubahan ideologi yang utama adalah penghormatan pada kualitas hidup (yakni berada dalam kondisi-kondisi nilai inheren) bukannya mempertahankan standar hidup yang makin tinggi. Selanjutnya akan muncul kesadaran mendalam terhadap perbedaan antara yang besar dan besar sekali (the difference between big and great); (8) Mereka yang mendukung poin-poin diatas memiliki kewajiban untuk menerapkan perubahan-perubahan mendesak tersebut, langsung maupun tidak langsung.

Berdasarkan pengetahuan dan pemahaman akan konteks tersebut, diharapkan akan membangun rasa kesadaran dan perasaan memiliki sebagai bagian dari suatu bangsa. Namun pada kenyataannya partisipasi Warga Negara dalam melestarikan lingkungan hidup perlu ditingkatkan, mengingat bukan hanya di Indonesia melainkan dunia saat ini sedang mengalami krisis lingkungan yang berakar pada kesalahan perilaku manusia yang berakar pada kesalahan perspektif manusia tentang manusia sendiri, alam, dan hubungan antara manusia dengan seluruh alam semesta (Keraf, Sony, 2006:123).

Untuk memperbaiki kesalahan perilaku dan kesalahan pandang manusia tentang dirinya dengan lingkungannya serta melakukan perubahan fundamental tentang cara pandang tersebut, bisa melalui "Citizenship Education" atau "Civic Education". Dengan kata lain "Citizenship Education" atau "Civic Education" dapat merubah cara pandang dan perilaku manusia atau warga negara dalam memandang lingkungannya. Civic Education, seyogyanya memiliki jati diri: diorganisasikan secara lintas bidang ilmu; difasilitasi dengan 
pembelajaran yang bersifat partisipatif dan interaktif; isi dan prosesnya dikaitkan pada kehidupan nyata; diselenggarakan dalam situasi yang demokratis; diupayakan agar mewadahi keanekaragaman sosial budaya masyarakat; dan dikembangkan bersama secara kolaboratif oleh sekolah, orang tua dan masyarakat termasuk pemerintah (Budimansyah, 2007: 29). Pengembangan Civic Education ini juga berkaitan erat dengan karakteristik warga negara yang disampaikan Cogan (1998). Cogan mengidentifikasi delapan karakteristik yang perlu dimiliki warga Negara sehubungan dengan semakin beratnya tantangan yang harus dihadapi dimasa mendatang. Karakteristik warga negara tersebut meliputi: (1) Kemampuan mengenal dan mendekati masalah sebagai warga Negara masyarakat global; (2) Kemampuan bekerjasama dengan orang lain dan memikul tanggung jawab atas peran atau kewajibannya dalam masyarakat; (3) Kemampuan untuk memahami, menerima, dan menghormati perbedaan-perbedaan budaya; (4) Kemampuan berfikir kritis dan sistematis; (5) Kemauan menyelesaikan konflik dengan cara damai tanpa kekerasan; (6) Kemauan mengubah gaya hidup dan pola makanan pokok yang sudah bisa, guna melindungi lingkungan hidup; (7) Memiliki kepekaan terhadap dan mempertahankan hak azasi manusia (seperti hak kaum wanita, minoritas etnis, dsb.); dan (8) Kemauan dan kemampuan berpartisipasi dalam kehidupan politik pada tingkatan pemerintahan lokal, nasional, dan internasional (Sapriya, 2004:9).

Dalam permasalahan lingkungan hidup khususnya Indonesia masih kurang adanya partisipasi Warga Negara salah satunya partisipasi hanya sebatas proyek selain itu kenyataannya masih banyak anggota masyarakat dalam hal ini oknum-oknum tertentu kurang sadar akan makna lingkungan hidup sehingga berdampak buruk pada lingkungan hidup, misalnya illegal logging, limbah industri pabrik, pencemaran udara, tanah, air, penebangan pohon dan lain-lain. Oleh karena itu partisipasi Warga Negara sangat dibutuhkan bukan hanya mengajak Warga Negara dalam proses pelaksanaan program ataupun proyek tetapi memberikan kesempatan untuk mengidentifikasi masalah, memecahkannya, membuat keputusan, melaksanakan, memonitoring, dan mengevaluasi.

Sejatinya, masyarakat bangsa kita yang telah sedemikian rupa digembleng habis-habisan melalui berbagai program Pendidikan Kewarganegaraan (baca: Citizenship Education) akan menjelma sebagai warga negara yang memiliki kekuatan karsa. Setidak-tidaknya jika kita mendefinisikan "Citizenship Education" sebagai program pendidikan yang mencakup pengalaman belajar di sekolah dan di luar sekolah, seperti yang terjadi di lingkungan keluarga, dalam organisasi keagamaan, dalam organisasi kemasyarakatan, dan dalam media (Cogan \& Derricott, 1998). Akan tetapi, kenyataannya hingga saat ini masyarakat bangsa kita masih dihiasi oleh suatu gejala kelemahkarsaan, suatu mentalitas yang sangat tidak cocok untuk pembangunan. (Budimansyah, 2006: 305). Hal ini juga akan berpengaruh terhadap kesadaran warga negara dalam menjaga kelestarian lingkungan hidup.

Pendidikan Kewarganegaraan mempunyai peran penting dalam penanaman nilai, karena koridornya value based, nilai tersebut harus diajarkan dalam pendidikan formal maupun non formal seperti PKn kemasyarakatan (community civics). Sedangkan objek studi Civics dan Pendidikan Kewarganegaraan (civic education) adalah warga negara dalam hubungannya dengan organisasi kemasyarakatan, sosial, ekonomi, agama dan negara. Sebagaimana dipaparkan oleh Somantri (2001: 276), dalam Lokakarya Metodologi Pendidikan Kewarganegaraan, (1973: 214) yang termasuk ke dalam objek studi civics ialah: (a) Tingkah laku, (b) Tipe pertumbuhan berfikir, (c) Potensi 
yang ada dalam setiap diri warga negara, (d) Hak dan kewajiban, (e) Cita-cita dan aspirasi, (f) Kesadaran (patriotisme, nasionalisme, pengertian internasional, dan moral Pancasila), dan (g) Usaha, kegiatan, partisipasi, dan tanggung jawab.

Pendidikan Kewarganegaraan merupakan salah satu wadah pembentukan warga negara yang baik (good citizenship), cerdas, terampil dan berkarakter setia kepada bangsa dan negara Indonesia dengan merefleksikan dirinya dalam kebiasaan berpikir dan bertindak sesuai dengan amanat Pancasila dan UUD NRI 1945.

Penanaman nilai-nilai lingkungan hidup sudah diintegrasikan kepada mata pelajaran pendidikan kewarganegaraan di dalam pendidikan formal meskipun pada proses pembelajaran belum sebagian guru PKn hanya sebatas memberikan materi saja belum sampai pengamalan nilai-nilai dan melestarikan lingkungan hidup.

Berbicara tentang Pendidikan Kewarganegaraan selain di persekolahan Pendidikan Kewarganegaraan juga dapat kita pelajari di masyarakat. Sebagaimana dikemukakan Cogan dalam Budimansyah dan Suryadi (2008:5) :

citizenship education or education for citizenship...The more inclusive term and encompasses both these in-school experiences as well as outof-school or non-formal/informal learning which takes place in the family, the religious organization, community organizations, the media etc, which help to shape the totality of the citizen.

Berdasarkan kutipan di atas citizenship education atau education for citizenship merupakan istilah generik yang mencakup pengalaman belajar di sekolah dan di luar sekolah, seperti yang terjadi di lingkungan keluarga, dalam organisasi keagamaan, dalam organisasi kemasyarakatan dan dalam media.

Tinjauan Pustakan dalam penulisan ini adalah.

\section{Partisipasi Warga Negara \\ Konsep Partisipasi}

Perhatian dan dukungan pemerintah terhadap pentingnya peran serta atau partisipasi sesungguhnya telah dimulai sejak awal 1960-an terutama bagi Negara maju seperti Amerika (lihat Smith, 1985). Di Negara berkembang, sejak terjadinya restorasi demokrasi atau reformasi politik pada akhir abad 20, keterlibatan warga dalam pengambilan kebijakan dalam pemerintahan lokal mulai diperhitungkan. Sebelumnya perkembangan demokrasi telah mengalami kehilangan makna yang mengarah pada autocratic dictatorship (Yunus, 2005). Dengan demikian, kebijakan pembangunan termasuk kebijakan pembangunan pada umumnya termasuk lingkungan hidup lebih bersifat top down, sehingga menimbulkan ketidakpedulian warga masyarakat terhadap apapun yang terjadi dalam perkembangan pembangunan.

Dinamika permasalahan yang dihadapi baik oleh pemerintah maupun masyarakat menuntut administrasi untuk melakukan pergeseran kinerjanya. Administrasi publik tidak lagi dapat memposisikan pemerintah sebagai aktor tunggal dalam kebijakan publik sebagaimana pandangan klasik administrasi publik (Henry, 2004: Denhardt dan Denhardt, 2002). Dalam era demokrasi, peran serta masyarakat dalam kebijakan publik merupakan sebuah keharusan. Ketika nilai-nilai demokrasi merambah kehidupan bermasyarakat maka nilai yang sama dituntut pula terjadi dalam praktik administrasi publik. Dengan kata lain partisipasi sebagai nilai dasar demokrasi menjadi perhatian penting dalam administrasi publik yang demokratis (Muluk, 2007).

Caiden (1982) penulis buku Public Administration, mengemukakan bahwa 
partisipasi publik merupakan kajian yang penting dalam kebijakan publik, oleh karena itu secara khusus dia memasukkan partisipasi sebagai ruang lingkup bahasannya. Partisipasi masyarakat dalam kebijakan publik diartikan sebagaiaktivitas yang dilakukanwarganegara, baik secara pribadi maupun berkelompok untuk mempengaruhi pembuatan keputusan pemerintah (Thoha,2005:76). Literatur lama dari Bum dan Peltason (1966), yakni Government by The People, mengelaborasi tentang pemerintahan yang demokratis dengan meletakkan nilai-nilai dasar demokrasi antara lain kebebasan warga untuk terlibat dalam kebijakan pemerintah. Untuk itu pemerintah yang demokratis harus memelihara keseimbangan antara kebebasan dan keteraturan, diantara keragaman dan keseragaman, dan diantara hak individu dan kepentingan umum.

Tulisan lain yang mengemukakan pentingnya partisipasi dalam kebijakan publik diantaranya Graham dan Phillips (1998) dalam buku Citizen Engagement: Lesson in Participation from Local Government. Prinsip-prinsip partisipasi masyarakat menurut mereka meliputi: pertama, the process should be community-based. Proses yang berlangsung harus didasarkan warga masyarakat, perspektif yang digunakan bukan atas dasar kepentingan pembuat kebijakan tetapi melalui cara pandang warga masyarakat. Kedua, citizen engagement should be connected to the political process. Dalam membangun partisipasi warga harus terdapat hubungan secara langsung dengan proses politik. Partisipasi warga yang berada diluar proses politik, akan tidak didengar oleh pengambil keputusan. Ketiga, citizen engagement should also involve publik education. Untuk memulai partisipasi, harus dengan pendidikan bagi warga tentang pentingnya perubahan. Keempat, the process should open regarding the options considered and emphasized. Dalam proses partisipasi harus ada keterbukaan dalam hal menentukan pertimbangan dan pilihan. Kelima, there is need for flexibility regarding methods of engagement and timing. Pada prinsipnya bahwa dalam partisipasi diperlukan variasi metode, dengan tujuan agar tercapai pesan yang diinginkan. Dan keenam, the process should be transparent. Dengan transparansi akan terjadi keterbukaan diantara elit dan warga atas berbagai informasi, meningkatkan bobot legitimasi, dan sebagai kontribusi pembelajaran pentingnya partisipasi warga negara.

Pendapat lain yang terkait dengan arti penting partisipasi dalam administrasi publik adalah King dan Stivers (1998) mengetengahkan posisi warga di era governance. Kata Government, dimaknai sebagai pemerintah yang selama ini terlalu dominan dan tidak melibatkan warga negara dalam keputusannya. Dalam tulisan tersebut diketengahkan bahwa dalam sejarah administrasi publik, warga dipandang bukan sebagai bagian yang menyatu dalam bidang administrasi publik. Partisipasi warga negara cukup ditempatkan atau diwakili pada proses legislatif melalui voting, yang acap kali tidak representatif. Oleh karena itu, dimunculkan pemikiran baru bahwa administrasi publik seharusnya warga negara sebagai warga (citizen) bukan sebagai pelanggan (customer). Dalam kesimpulan tulisan tersebut disebutkan bahwa "Government is us is a democratic publik administration that involves active citizenship and active administrations". Administrasi publik yang demokratis jika melibatkan warga negara dan pemerintah secara aktif. Dengan demikian akan terjadi hubungan yang egaliter antara warga negara dan pemerintah.

Islamy (2004) menyatakan paling tidak ada 8 (delapan) manfaat yang akan dicapai jika melibatkan partisipasi masyarakat di dalam pembangunan, yakni: pertama, masyarakat akan semakin siap untuk menerima dan melaksanakan gagasan pembangunan. Kedua, hubungan masyarakat, pemerintah, 
Tabel 1

Arah Perubahan Partisipasi

\begin{tabular}{ll}
\hline \multicolumn{1}{c}{ Dari } & \multicolumn{1}{c}{ Menuju } \\
\hline Pemanfaatan (Beneficiary) & Warga (Citizen) \\
\hline Diposisikan sebagai proyek (Project) & Masuk dalam kebijakan (Policy) \\
\hline Konsultasi (Consultation) & Pengambil keputusan (Decision-making) \\
\hline Lebih sebagai pendekatan (Appraisal) & $\begin{array}{l}\text { Lebih nyata, karena menekankan pada } \\
\text { implementasi (Implementation) }\end{array}$ \\
\hline Pada tataran mikro (Micro) & Pada tataran makro (Macro) \\
\hline
\end{tabular}

\section{Sumber: Cornwall and Gaventa, (2001)}

dan legislatif akan semakin baik. Ketiga, masyarakat mempunyai komitmen yang tinggiterhadapinstitusi. Keempat, masyarakat mempunyai kepercayaan yang lebih besar kepada pemerintah dan legislatif serta bersedia bekerjasama dalam menangani tugas dan urusan publik. Kelima, bila masyarakat telah memiliki kepercayaan, dan menerima ide-ide pembangunan maka mereka juga akan mewujudkan ide-ide tersebut. Keenam, mutu/kualitas keputusan/kebijakan yang diambil akan menjadi semakin baik karena masyarakat turut serta memberikan masukan. Ketujuh, akan memperlancar komunikasi. Kedelapan, dapat memperlancar kerjasama terutama untuk mengatasi masalah-masalah bersama yang komplek dan rumit.

Konsep partisipasi dari Peter sejalan dengan konsep partisipasi dalam perspektif good governance (Cornwall and Gaventa, 2001). Dalam konteks ini, partisipasi diarahkan ke dalam bentuk yang lebih langsung. Pada prinsipnya adalah bagaimana masyarakat dapat mempengaruhi pemerintah dan memaksa agar lebih accountable. Terkait dengan hal ini, mereka menilai terdapat perubahan bentuk partisipasi dan tekanan pada demokrasi, sebagaimana tabel 1 .

Dalam kesempatan yang lain, Gaventa (2002) dalam tulisannya berjudul Introduction: Exploring Citizenship, Participation and accountability, mengemukakan keterkaitan partisipasi dengan kewarganegaraan dan akuntabilitas. Dikatakan bahwa pada masa yang lampau, terdapat dua kecenderungan dalam menghadapi kesenjangan yang ada antara warga dan lembaga pemerintahan. Di satu pihak, hal ini diatasi dengan memperkuat proses partisipasi untuk mempengaruhi lembaga yang lebih besar dalam proses penyusunan kebijakan. Diantaranya tercermin dalam tabel diatas jika semula warga dirumuskan sebagai pemanfaatan (beneficiaries), saat ini sudah harus diposisikan sebagai pihak yang berhak dan sah dalam pembangunan. Partisipasi warga lebih politis dan berdasarkan pendekatan hak memungkinkan warga menjadi pembuat dan penajam (maker and shaper) programprogram pembangunan mereka sendiri. Cornwall and Gaventa (2001), kemudian melihat secara lebih dekat bagaimana seharusnya bentuk dan ruang partisipasi itu terjadi. Namun, diakui bahwa tidak ada bentuk partisipasi yang netral, melainkan ada bentuk partisipasi yang berhubungan dengan kekuasaan. Oleh karena itu, yang diperlukan adalah perhatian lebih yang harus diberikan pada siapapun, tujuannya adalah untuk menciptakan hubungan sosial, sumber daya dan pengetahuan agar berjalan dengan efektif.

Di sinilah letak dilema partisipasi warga, di satu sisi sebagai bagian dari proses demokrasi, partisipasi merupakan sebuah keniscayaan. Di lain pihak, tidak mudah membangun partisipasi yang netral, bebas dari pengaruh kekuasaan. Burke, jauh hari, berpuluh tahun yang lalu (1968) telah menyampaikan kegalauan ini. Dalam tulisannya yang diberi judul Citizen Participation Strategis, mengemukakan dalam partisipasi warga 
(participatory democracy), tidak dapat dilepaskan dari konflik nilai, yakni konflik diantara kebebasan, yang diwakili warga di satu sisi, dan kekuasaan, yakni pemerintah, di pihak lain. Nelson dan Wright (1995), mengemukakan hal senada dengan pandangan Burke. Dikatakan bahwa ketika kekuasaan dikaitkan dengan partisipasi, maka satu pihak akan mempengaruhi pihak yang lain untuk bertindak merealisasikan kehendak pihak yang berpotensi menguasai. Kekuasaan merupakan bagian dari sistem kehidupan sehari-hari tidak terkecuali dalam kaitannya dengan partisipasi warga.

Partisipasi yang bermakna adalah partisipasi yang dapat mendorong proses belajar bersama, yang mampu membuat komunikasi yang seimbang dalam membahas persoalan publik, sehingga menghasilkan kesepakatan dalam pengambilan keputusan di tingkat politik formal, keputusan tersebut harus dilaksanakan sesuai dengan tujuan yang telah ditetapkan dan disepakati. Sebagaimana teori dan ideologi dasar partisipasi yang dikemukakan World Bank. Dua kata kunci dalam strategi partisipasi adalah stakeholders dan transformative Nelson dan Wright (1995). Keduanya diturunkan dari teori tentang bagaimana masyarakat diorganisir dan bagaimana masyarakat dapat berubah. Artinya dalam partisipasi melibatkan stakeholder yang saling berinteraksi dalam menstransformasikan nilai-nilai pembangunan kearah yang lebih baik.

Dalamkonteksini, Burke(1999)menganalisis partisipasi warga bukan sebagai nilai, tetapi lebih sebagai strategi, dan syarat-syarat organisasi. Diidentifikasi oleh Burke terdapat 5 (lima) strategi dalam partisipasi yakni: terapi pendidikan (education therapy), perubahan perilaku (behavioral change), penambahan staf (staff supplement), kooptasi (cooptation), dan kekuasaan warga (community power). Pertama, pendidikan dalam konteks ini adalah mengadakan pelatihan kepada warga, dimana warga bekerja secara bersama-sama untuk menyelesaikan berbagai persoalan masyarakat, bukan hanya bagaimana belajar tentang bagaimana demokrasi bekerja tetapi juga belajar mengenai nilai dan menghargai kerjasama sebagai metode untuk menyelesaikan permasalahan (problem solving). Dalam hal ini akan dilakukan penguatan pemerintahan lokal, mendorong pembangunan masyarakat, dan membangun identitas masyarakat.

Kedua, strategi perubahan perilaku (behavioral change), merupakan upaya merubah perilaku kearah deliberative, dan ditujukan untuk mempengaruhi individu melalui kesertaan dalam kelompok. Dengan strategi ini akan lebih mudah untuk merubah perilaku individu yang tergabung dalam kelompok dibanding yang terpisah. Disamping itu dapat individu dan kelompok disertakan dalam partisipasi sejak tahap pengambilan keputusan. Ketiga, penambahan staff (staff supplement), merupakan strategi dasar dalam asosiasi suka rela. Keempat, kooptasi (cooptation), memberikan masukan untuk mempengaruhi kebijakan, dan Kelima, kekuasaan warga (community power), dimana sebagian besar kekuasaan warga dapat memberikan pengaruh dalam pengambilan keputusan.

Sementara Pretty (1995), mengklasifikasi partisipasi, terdiri dari 6 (enam) klasifikasi sebagai berikut: (1) Partisipasi pasif atau manipulative.Inimerupakanbentukpartisipasi yang paling lemah. Karakteristiknya adalah masyarakat menerima pemberitahuan apa yang sedang dan telah terjadi. Pengumuman sepihak oleh pelaksana proyek tidak memperhatikan tanggapan masyarakat sebagai sasaran program. Informasi yang dipertukarkan terbatas pada kalangan professional diluar kelompok sasaran belaka; (2) Partisipasi informative. Masyarakat menjawab pertanyaan-pertanyaan penelitian untuk proyek, namun tidak berkesempatan untuk terlibat dan mempengaruhi proses penelitian. Akurasi hasil penelitian, tidak 
dibahas bersama masyarakat; (3) Partisipasi konsultatif. Masyarakat berpartisipasi dengan cara berkonsultasi, sedangkan orang luar mendengarkan, menganalisa masalah dan pemecahannya. Belum ada peluang untuk pembuatan keputusan bersama. Para professional tidak berkewajiban untuk mengajukan pandangan masyarakat (sebagai masukan) untuk ditindaklanjuti; (4) Partisipasi insentif. Masyarakat memberikan pengorbanan barang dan jasa untuk memperoleh imbalan insentif berupa upah, walau tidak dilibatkan dalam proses pembelajaran atau eksperimen-eksperimen yang dilakukan. Masyarakat tidak memiliki andil untuk melanjutkan kegiatan-kegiatan setelah insentif dihentikan; (5) Partisipasi fungsional. Masyarakat membentuk kelompok-kelompok sebagai bagian dari proyek, setelah ada keputusan-keputusan utama yang disepakati. Pada tahap awal, masyarakat tergantung pada pihak luar, tetapi secara bertahap menunjukkan kemandiriannya; (6) Partisipasi interaktif. Masyarakat berperan dalam analisis untuk perencanaan kegiatan dan pembentukan atau penguatan kelembagaan. Cenderung melibatkan metode interdisipliner yang mencari keragaman perspektif dalam proses belajar yang terstruktur dan sistematis. Masyarakat memiliki peran untuk mengontrol atas pelaksanaan keputusankeputusan mereka, sehingga memiliki andil dalam keseluruhan proses kegiatan; dan (7) Mandiri (self-mobilization). Masyarakat mengambil inisiatif sendiri secara bebas (tidak dipengaruhi pihak luar) untuk merubah sistem atau nilai-nilai yang mereka junjung. Mereka mengembangkan kontak dengan lembaga-lembaga lain untuk mendapatkan bantuan dan dukungan teknis serta sumber daya yang diperlukan. Masyarakat memegang kendali atas pemanfaatan sumber daya yang ada dan atau digunakan. Istilah partisipasi digunakan secara luas dalam literatur-literatur pembangunan, dan dengan beragam interpretasi. Secara posisional, ia berada dalam range dari suatu kondisi kontrol luar yang hamper total lalu pada keterlibatan local people, sampai kepada bentuk aksi kolektif masyarakat lokal yang menyusun dan mengimplementasikan rencana mereka sendiri dan absesnya inisiasi dan fasilitator dari luar.

Dengan kata lain, meskipun terjadi perbedaan sudut pandang dari para ahli dalam merumuskan konsep partisipasi, namun pada hakekatnya mereka berada dalam satu bangunan. Pada prinsipnya para ahli sepakat perlunya diberikan ruang yang lebih luas bagi warga dalam turut serta proses kebijakan publik. Pertanyaannya adalah seberapa tinggi derajat partisipasi yang dapat dilakukan oleh warga. Mengingat dari berbagai konsep yang ada, partisipasi warga tidak berdiri sendiri, tetapi dia harus berhubungan dengan stakeholder yang lain yaitu pemerintah dan pasar. Para ahli selanjutnya mengkategorikan partisipasi yang pada umumnya dikaitkan dengan kekuasaan pemerintah atas warga.

\section{Derajat Partisipasi}

Salah satu konsep partisipasi yang sangat popular sejak empat puluh tahun yang lalu adalah tangga partisipasi dari Arsntein. Pada bulan Juli 1969, Arsntein mempublikasikan tulisannya dengan judul "A Ladder of Citizen Participation" dalam Journal of the American Institute of Planners. Pemikiran Arnstein ini berangkat dari pengalamannya dalam program sosial, perbaikan perkotaan, kemiskinan, dan model kota. Idenya lebih kearah "provokatif" dan difokuskan pada redistribusi kekuasaan sebagai elemen yang penting dalam memaknai partisipasi warga. Tangga partisipasi Arnstein ini terdiri dari delapan anak tangga tersebut dibagi ke dalam 3 (tiga) kategori besar. Kategori pertama yakni non partisipasi, terdiri dari manipulasi dan terapi, kedua, yakni derajat tanda partisipasi mencakup pemberian informasi, konsultasi, penentraman, dan kemitraan, dan ketiga, derajat kuasa warga terdiri dari delegasi kekuasaan, dan control warga. 


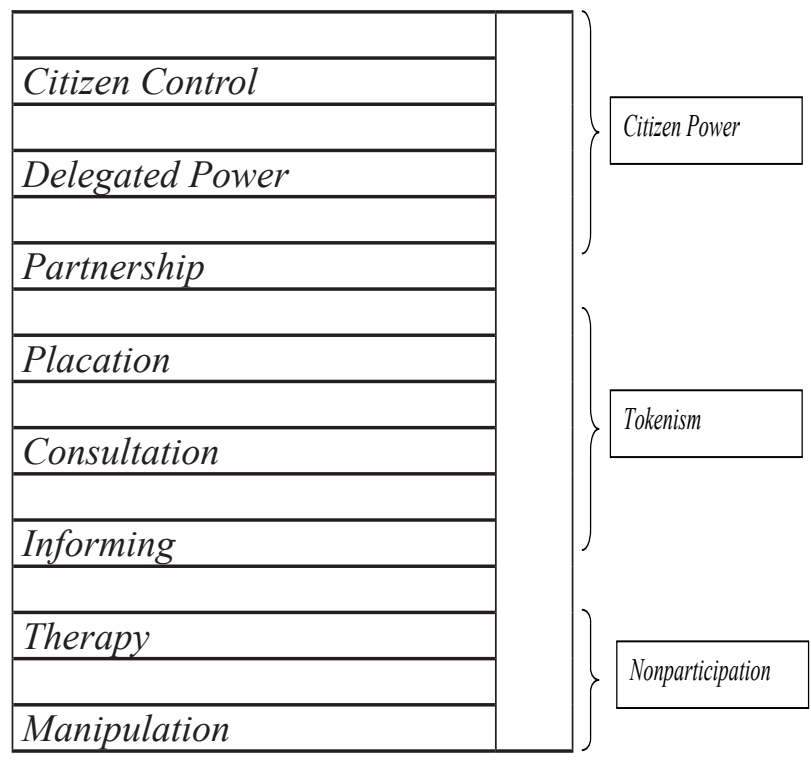

Sumber: Arnstein, (1970:70)

Gambar 1. Tangga Patisipasi Sherry Arnstein

Secara singkat kedelapan tangga tersebut dapat dijelaskan: 1) manipulasi lebih sebagai permainan oleh pemerintah, merupakan derajat partisipasi terendah. Pada tahap ini yang terjadi adalah adanya permainan pemerintah. Sehingga pada tahap ini dapat dikatakan tidak ada partisipasi masyarakat; 2) terapi, juga termasuk dalam derajat non partisipasi, pada tahap ini sekedar agar warga tidak marah atau hanya mengobati kekecewaan warga; 3) pemberitahuan atau pemberian informasi, sekedar pemberitahuan searah/sosialisasi dari pemerintah atau pihak yang berwenang kepada publik; 4) konsultasi masyarakat, merupakan derajat tokenism, yang lebih tinggi derajatnya satu tingkat dari informasi. Disini sidah terdapat komunikasi dua arah antara warga dan pemerintah. Masyarakat didengar, tetapi tidak selalu dipakai sarannya; 5) penentraman, saran masyarakat diterima, tetapi tidak selalu dilaksanakan; 6) kemitraan, terdapat pelibatan warga yang lebih mendalam, terjadi timbalebalik hubungan dan dinegosiasikan; 7) pendelegasian, yakni memposisikan derajat warga pada derajat kuasa warga, masyarakat diberi kekuasaan Tingkatan kekuasaan ada di Kekuasaan (sebagai atau seluruh masyarakat Program); 8) Kontrol, merupakan derajat tertinggi, yang memberikan keterlibatan warga masyarakat secara lebih kuat, sepenuhnya dikuasai oleh masyarakat.

Meskipun pendapat Arnstein, hingga saat ini banyak diikuti oleh ahli-ahli yang lain, terutama jika dikaitkan dengan partisipasi warga dalam pembangunan, tetap saja tidak terbebas dari kritik. Kritik yang dilontarkan terutama dikaitkan dengan kerancuan antara partisipasi dan control kekuasaan. Bagi Arnstein, jika warga telah dapat sepenuhnya melakukan kontrol, maka dapat dimaknai partisipasi warga telah mencapai derajat yang paling tinggi yaitu kendali/kekuasaan warga. Berbeda dengan Arnstein, menurut Burn, Hambleton, dan Hogget (1994), bahwa anak tangga partisipasi bisa lebih dari delapan anak tangga dengan jarak yang tidak sama. Mereka kemudian mengemukakan konsep tangga pemberdayaan yang terdiri dari 12 (dua belas) anak tangga. Sama halnya dengan Arnstein derajat terendah yakni non partisipasi warga, namun pada tangga pertama ini terdiri dari 4 (empat) anak tangga yang meliputi: penipuan warga (civic hype), konsultasi sinis (cynical consultation), informasi yang buruk (poor information), dan pemeliharaan pelanggan (customer care). Derajat partisipasi yang kedua adalah partisipasi warga (citizen 
Tabel 2

Bentuk Partisipasi

\begin{tabular}{|c|c|c|}
\hline Bentuk Partisipasi & Tipe Partisipasi & $\begin{array}{c}\text { Peran masyarakat lokal } \\
\text { sebagai }\end{array}$ \\
\hline 1. Co-option & $\begin{array}{l}\text { Tidak ada input apapun dari } \\
\text { masyarakat lokal yang dijadikan } \\
\text { bahan }\end{array}$ & Subjek \\
\hline 2. Cooperation & $\begin{array}{l}\text { Terdapat insentif, namun proyek telah } \\
\text { didesain pihak luar yang menentukan } \\
\text { seluruh agenda dan proses secara } \\
\text { langsung }\end{array}$ & $\begin{array}{l}\text { Employees atau } \\
\text { subordinat }\end{array}$ \\
\hline 3. Consultation & $\begin{array}{l}\text { Opini masyarakat ditanya, namun } \\
\text { pihak luar menganalisis informasi } \\
\text { sekaligus memutuskan bentuk aksinva }\end{array}$ & Clients \\
\hline 4. Collaboration & $\begin{array}{l}\text { Masyarakat lokal kerjasama dengan } \\
\text { pihak luar untuk menentukan prioritas, } \\
\text { dan pihak luar bertanggung jawab } \\
\text { secara langsung kepada proses }\end{array}$ & Collaborators \\
\hline 5. Co-learning & $\begin{array}{l}\text { Masyarakat lokal dan luar saling } \\
\text { membagi pengetahuannya untuk } \\
\text { memperoleh saling pengertian, dan } \\
\text { bekerjasama untuk merencanakan } \\
\text { aksi, sementara pihak luar hanya } \\
\text { memfasilitasi }\end{array}$ & Partners \\
\hline 6. Collective action & $\begin{array}{l}\text { Masyarakat lokal menyusun dan } \\
\text { melaksanakan agendanya sendiri, } \\
\text { pihak luar absen sama sekali. }\end{array}$ & Directors \\
\hline
\end{tabular}

Sumber: Syahyuti (2005)

participation), yang memiliki 6 (enam) anak tangga, jumlah anak tangga ini lebih banyak dibanding konsep Arnstein. Keenam anak tangga tersebut adalah informasi berkualitas (high quality information), konsultasi yang asli (genuine consultation), badan penasehat yang efektif (effective advisory board), desentralisasi terbatas pada pembuatan keputusan (limited decentralized decision making), kemitraan partnership, dan pengawasan yang didelegasikan (delegated control). Adapun yang termasuk dalam derajat partisipasi yang tertinggi adalah kembali yang dipercayakan (entrusted control), dan kendali interdependensi (interdependent control).

Secara garis besar pendapat Burn, Hambleton, dan Hogget (1994), sejalan dengan Arnstein yakni derajat partisipasi dibagi 3 (tiga) kategori besar, meskipun dalam beberapa hal terdapat perbedaan pandangan. Jika Arnstein membagi ketiga kategori tersebut ke dalam 8 anak tangga, sementara Burn,
Hambleton, dan Hogget (1994), membaginya ke dalam 12 anak tangga. Disamping itu, pada kategori ketiga, yakni control warga bagi Burn, Hambleton dan Hogget (1994), sejatinya bukan lagi sebagai partisipasi. Menurut mereka pada derajat ketiga ini, lebih merupakan control dibanding partisipasi. Meskipun demikian, dalam konsepnya mereka tetap mencantumkan kategori ketiga sebagai derajat partisipasi tertinggi.

Ahli yakni Biggs (1989), Cornwall and Jawkes (1995) dan Parkes dan Panelli (2001), juga memiliki jalan pikir yang sama dengan Arnstein, yakni adanya derajat atau tingkatan dalam partisipasi. Dari kajian mereka terdapat 6 (enam) kategori bentuk partisipasi yang secara berurutan semakin baik (tabel 2.3). dalam penjelasannya disebutkan bahwa dilihat dari segi control pihak luar semakin menurun dari tipe 1 sampai 6, bahkan pada tipe 6 kontrolnya nol. Sebaliknya potensi untuk keberlanjutan aksi dan rasa kepemilikan lokal semakin meningkat. Pada 
tipe 1 sampai 3 potensi keberlanjutannya nol, dan pada tipe 6 potensinya paling tinggi. Mereka menggambarkan secara berlawanan antara control pihak luar dengan potensi partisipasi warga. Dengan kata lain semakin kecil control dari pihak luar, maka semakin besar derajat partisipasi warga. Disamping itu, kategori mereka secara lebih jelas memposisikan peran masyarakat lokal, dibanding model Arnstein, Burn, Hambleton, dan Hogget.

Disisi lain, para ahli menilai partisipasi warga pada hakekatnya merupakan kemitraan dari multistakeholder. Di dalam kemitraan ini terlibat berbagai unsur yaitu: Negara, perusahaan dan aktor privat yang lain, NGO, dan berbagai komunitas yang lain. Ide dari kemitraan multistakeholder ini didasari pada kolaborasi paradigm manajemen. Yang belakangan ini didefinisikan sebagai berbagai kekuasaan dan tanggung jawab pemerintah dan penggunaan sumber daya lokal (Carisson and Berkes, 2003). Dalam konsep ini Negara di mungkinkan untuk dapat membangun kemitraan dengan stakeholder lokal. Dimana dalam proses pengambilan keputusan terdapat keseimbangan antara Negara dengan stakeholder lokal.

\section{METODE PENELITIAN}

Pendekatan pengkajian yang penulis gunakan adalah pendekatan kualitatif, yaitu suatu pendekatan menurut Vernon van Dyke pada prinsipnya adalah ukuranukuran untuk memilih masalah-masalah dan data-data yang bertalian satu sama lainnya. Rumusan selengkapnya van Dyke (1965: 114) mengemukakan" An approach consists or criteria of selection-criteria employed in selecting the problems or questions to consider and in selecting the data to bring to bear, it consists of standards governing the inclusion of questions and data."

Suatu pendekatan terdiri dari ukuranukuran-ukuran pemilihan, ukuran-ukuran yang dipergunakan dalam memilih masalahmasalah atau pernyataan-pernyataan untuk dipertimbangkan dan dalam memilih data yang perlu diadakan; ini terdiri dari ukuranukuran-ukuran baku yang menetapkan pemasukan atau pengeluaran pernyataanpernyataan dan data.

Kerlinger memperjelas pernyataan tersebut, dengan menggunakan istilah pendekatan ilmiah yang dapat dilihat secara sistematis dari seluruh pemikiran dalam menelaah pendekatan dapat dilakukan berdasarkan sudut pandang ataupun tinjauan dari berbagai satu kesatuan karakteristik maupun cabang ilmu seperti; sosiologi, antropologi, sejarah, psikologi, geografi, ekonomi, politik, dan sebagainya. Penelitian ini menggunakan pendekatan kualitatif dijadikan ukuran secara konsisten. jadi dalam penelitian ini penulis tidak menggunakan perhitungan-perhitungan secara matematis dan statistik, melainkan lebih menekankan kepada kajian deskriptif dan interpretasi.

Strauss dan Corbin (1997) dalam bukunya Basic of Qualitative Research, yang dimaksud penelitian kualitatif adalah jenis pengkajian yang menghasilkan penemuanpenemuan yang tidak dapat dicapai dengan menggunakan prosedur-prosedur statistikatau cara-cara lain dari kuantifikasi. Selanjutnya, sebagaimana dikatakan Bogdan dan Biklen (1992), bahwa pendekatan kualitatif memiliki bingkai aslinya (natural setting), karena data dikumpulkan dari sumbernya langsung dan penulis sebagai instrumen utama pengkajian. Dengan aktivitas awal mengidentifikasi konsep inovasi dan reorientasi terhadap teori warga Negara dan teori lingkungan hidup, penelitian ini dirancang dalam dua aktivitas. Aktivitas pertama menggali data terkait dengan upaya mendeskripsikan konteks teori warga Negara dan teori lingkungan hidup yang perlu direorientasikan dan kedua terkait dengan aktivitas menemukenali dan mendeskripsikan konsep Green Moral yang relevan untuk disajikan sebagai penguatan 
partisipasi warga Negara dalam pelestarian lingkungan hidup.

Beberapa literatur menyebutkan ciri-ciri penelaahan kualitatif/naturalistik, antara lain, sumber data adalah situasi wajar (natural setting), peneliti sebagai instrumen utama pengumpul data penelitian (key, instrument), sangat deskriptif, mementingkan proses, mengutamakan data langsung (first hand), triangulasi (data dari satu sumber harus dicek kebenarannya dengan cara memperoleh data yang sama dari sumber lain), mementingkan perspektif emic (pandangan responden), sampling purposif, audit-trail (apakah laporan penelitian sesuai data yang terkumpul), partisipasi tanpa mengganggu (passive participation), analisis dilakukan sejak awal dan selama melakukan penelitian, dan desain penelitian muncul selama proses penelitian (emergent, evolving dan developing).

Pendekatan kualitatif dipandang sesuai dengan masalah penelitian ini dengan beberapa alasan:

1. Penulis mencoba mengungkap dokumen penguatan partisipasi warga Negara dalam pelestarian hidup. Adapun alasan penulis menggunakan dokumen tersebut sebagai mana dikemukakan Guba \& Lincoln dalam A. Chaedar Alwasilah (2003:156): (a) Dokumen merupakan sumber informasi yang lestari; (b) Dokumen merupakan bukti yang dapat dijadikan dasar untuk mempertahankan diri terhadap tuduhan atau kekeliruan interprestasi; (c) Dokumen itu sumber data alami, bukan hanya muncul dari konteksnya, tetapi juga menjelaskan konteks itu sendiri; (d) Dokumen itu relatif mudah dan murah; (e) Dokumen itu sumber data yang non reaktif; dan (f) Dokumen berperan sebagai sumber pelengkap dan memperkaya bagi informasi yang diperoleh melalui interview atau observasi.

2. Pengkajian ini berfokus pada "Penguatan Partisipasi Warga Negara dalam Menjaga
Kelestarian Lingkungan Hidup Menuju Pembangunan Berkelanjutan berbasis Konsep Green Moral. Hal ini dapat terungkap melalui pendekatan kualitatif sesuaidengankarakteristik kualitatifyang dikemukakan oleh Bogdan \& Blinken (1982:28): "qualitative researchers are concerned with process rather than simply with outcomes or products". Penekanan kualitatif pada proses secara khusus memberi keuntungan dalam penelitian pendidikan.

Penulisan ini mencoba mengungkap bagaimana Penguatan Partisipasi Warga Negara dalam Menjaga Kelestarian Lingkungan Hidup Menuju Pembangunan Berkelanjutan berbasis Konsep Green Moral.

Desain penelitian kualitatif tidak didasarkan pada suatu kebenaran yang mutlak, tetapi kebenaran itu sangat komplek karena selalu dipengaruhi oleh faktor-faktor sosial, histories, serta nilai-nilai. Menurut Nasution (1996:17), pengkajian kualitatif sebenarnya meliputi sejumlah penelitian antara lain: kerja lapanganpenelaahan lapangan, studi kasus dan lain-lain. Mengenai metode studi kasus Winarno Surakhmad (1998:143) mengemukakan bahwa:

Studi kasus memusatkan perhatian pada kasus secara intensif dan mendetail. Kasus dapat terbatas pada satu orang, satu lembaga, satu keluarga, satu peristiwa, satu desa, ataupun satu kelompok manusia dan kelompok objek lain-lain yang cukup terbatas yang dipandang sebagai kesatuan. Dalam hal itu cukup segala aspek kasus tersebut mendapat perhatian sepenuhnya dari penyelidik itu adalah segala sesuatu yang mempunyai arti dalam riwayat kasus, misalnya peristiwa terjadinya, perkembangan dan perubahan-perubahannya.

Penelaahan kualitatif dengan menelaah kasus dianggap tepat untuk penelitian ini karena yang menjadi fokus penelaahan adalah kasus yang terjadi di masyarakat yaitu mengenai penggalian dan pengkajian berbagai 
literature tentang penguatan partisipasi warga Negara dalam pelestarian lingkungan hidup di Kabupaten Blitar. Melalui pendekatan kualitatif dengan beberapa kasus ini akan lebih luas dan mendalam mengungkap Penguatan Partisipasi Warga Negara dalam Menjaga Kelestarian Lingkungan Hidup Menuju Pembangunan Berkelanjutan berbasis Konsep Green Moral.

\section{HASIL DAN PEMBAHASAN}

\section{Kabupaten Blitar}

Kabupaten Blitar adalah salah satu kabupaten di Provinsi Jawa Timur, Indonesia. Pusat pemerintahan kabupaten ini berada di Kanigoro setelah sebelumnya satu wilayah dengan Kota Blitar.

Kabupaten Blitar memiliki 22 kecamatan yang dibagi lagi menjadi 220 desa dan 28 kelurahan dengan luas wilayah $1.588,79 \mathrm{~km}^{2}$.

- Batas wilayah

Utara : Kabupaten Kediri dan Kabupaten Malang

Selatan: Samudera Hindia

Barat :Kabupaten Tulungagung dan Kabupaten Kediri

Timur : Kabupaten Malang

Gunung Kelud (1.731 m. dpl.) adalah salah satu gunung api strato yang masih aktif di Pulau Jawa yang terletak di bagian utara kabupaten ini berbatasan langsung dengan Kabupaten Kediri. Bagian selatan Kabupaten Blitar yang dipisahkan oleh Sungai Brantas dikenal sebagai penghasil kaolin dan dilintasi oleh Pegunungan Kapur Selatan. Pantai yang terkenal antara lain Pantai Tambakrejo, Serang dan Jalasutra.

Blitar, baik kota maupun kabupaten, terletak di kaki Gunung Kelud, Jawa Timur. Daerah Blitar selalu terkena lahar Gunung Kelud yang sudah meletus puluhan kali terhitung sejak tahun 1331. Lapisan-lapisan tanah vulkanik yang banyak ditemukan di Blitar pada hakikatnya merupakan hasil pembekuan lahar Gunung Kelud yang telah meletus secara berkala sejak bertahun-tahun yang lalu.

Keadaan tanah di daerah Blitar yang kebanyakan berupa tanah vulkanik, mengandung abu letusan gunung berapi, pasir dan napal (batu kapur yang tercampur tanah liat). Tanah tersebut pada umumnya berwarna abu-abu kekuningan, bersifat masam, gembur dan peka terhadap erosi. Tanah semacam itu disebut regosol yang dapat dimanfaatkan untuk menanam padi, tebu, tembakau dan sayur mayur. Selain hijaunya persawahan yang kini mendominasi pemandangan alam di daerah Kabupaten Blitar, ditanam pula tanaman tembakau di daerah ini. Tembakau ini mulai ditanam sejak Belanda berhasil menguasai daerah ini sekitar abad ke-17. Bahkan kemajuan ekonomi Blitar pernah ditentukan dengan keberhasilan atau kegagalan produksi tembakau.

\section{Bentuk - Bentuk Partisipasi Warga Negara}

Berdasarkan hasil pengamatan di lapangan, wawancara dan data dokumentasi yang dilakukan peneliti selama pengumpulan data, dalam bab 4 ini akan dideskripsikan temuan penelitian tentang: Penguatan Partisipasi warga Negara dalam Pelestarian Lingkungan Hidup menuju Pembangunan Berkelanjutan berbasis Konsep Green Moral. Secara rinci hasil penelitian akan diuraikan dalam empat sub bagian, yaitu: (a) Bentuk-bentuk partisipasi warga negara dalam pelestarian lingkungan hidup; (b) Kompetensi kewarganegaraan agar warga negara dapat berpartisipasi dalam pelestarian lingkungan hidup; (c) Bentuk penguatan partisipasi warga negara dalam pelestarian lingkungan hidup; (d) Partisipasi warga negara dalam pelestarian lingkungan hidup berdasar konsep green moral pada pembangunan berkelanjutan; (e) Faktor pendukung dan penghambat dalam membangun partisipasi warga negara dalam pelestarian lingkungan 
hidup.

\section{Bentuk-bentuk Partisipasi Warga Negara dalam Pelestarian Lingkungan Hidup}

Bentuk-bentukpartisipasiwarganegara dalam pelestarian lingkungan hidup berdasarkan hasil wawancara di masyarakat, sekolah, dan dinas terkait dapat diklasifikasikan menjadi berbagai macam kegiatan.

a. Pemberdayaan masyarakat melalui kegiatan rutin

Bentuk partisipasi warga negara dalam pelestarian lingkungan hidup selama ini berupa pengelolaan sampah yang dilakukan mandiri, terpadu dan gotong royong sebagai bentuk pemberdayaan. Hal ini mencerminkan adanya kesadaran masyarakat dan kemauan dalam pelestarian lingkungan hidup hal tersebut sesuai hasil wawancara dengan tokoh masyarakat, masyarakat, instansi terkait A1 yang mengungkapkan bahwa:

"Dalam mewujudkan wilayah RW 04 menjadi RW yang peduli lingkungan hijau, bersih, tertib, rapi, indah dan nyaman melaksanakan beberapa inovasi yaitu: (1) pembangunan gotong-royong berbasis RT, (2) pengelolaan sampah mandiri berbasis masyarakat yang dikembangkan dengan pengelolaan sampah model: Sistem Manajemen Sampah-SMS, (3) perwujudan lingkungan RWBerbasis Green and Clean, (4) budidaya sayur-mayur pada lahan perumahan yang sempit. Pembangunan gotong royong berbasis RT yang muncul tahun 2009 dilatarbelakangi program pembangunan tingkat RW yang tidak dapat berjalan maksimal. Kondisi ini disebabkan masyarakat RW 04 memiliki karakter individualisme yang tinggi. Kemudian pengurus RW 04 mencari solusi agar karakteristik tersebut dapat dimanfaatkan semaksimal mungkin dalam mewujudkan inovasi baru, yakni pembangunan gotong-royong berbasis RT. Inovasi ini dimulai pada tahun 2009, dengan pelaksanaan pembangunan pavingisasi jalan blok dan perbaikan drainase."

Tabel 3

Bentuk-bentuk Partisipasi Warga Negara dalam Pelestarian Lingkungan Hidup

\begin{tabular}{|c|c|c|}
\hline \multirow{2}{*}{ Tempat } & \multicolumn{2}{|l|}{ Kabupaten Blitar } \\
\hline & Nilai & Bentuk Partisipasi \\
\hline Sekolah & $\begin{array}{l}\text { a. Cinta lingkungan hidup } \\
\text { b. Cinta kebersihan } \\
\text { c. Kepedulian }\end{array}$ & $\begin{array}{l}\text { a. Sekolah Adiwiyata Award } \\
\text { b. Dua sekolah SD, satu sekolah SMP, } \\
\text { satu sekolah SMA }\end{array}$ \\
\hline Masyarakat & $\begin{array}{l}\text { a. Gotong royong } \\
\text { b. Tanggung jawab dalam bentuk } \\
\text { pemeliharaan mata air } \\
\text { c. Kepedulian } \\
\text { d. Kekeluargaan }\end{array}$ & $\begin{array}{l}\text { a. Pemeliharaan sumber air } \\
\text { b. Penanganan lahan kritis } \\
\text { c. Penyelenggaraan adipura }\end{array}$ \\
\hline
\end{tabular}

Sumber : M. Syahri 2013

Hal tersebut diperkuat oleh pendapat A2 tentang bentuk-bentuk partisipasi Warga Negara dalam pelestarian lingkungan hidup di Kota Batu yang diterjemahkan oleh Dinas Pendidikan dan Kebudayaan berupa; dimasukkannya secara resmi Pendidikan Lingkungan Hidup dalam kurikulum dan disusun Modul materi Lingkungan Hidup tingkat Sekolah Dasar sampai Sekolah Menengah Atas. Serta mengikuti Lomba sekolah berbasis lingkungan hidup: Adiwiyata Award.

Selanjutnya Hermawan Staff Kantor Lingkungan Hidup Kabupaten Blitar menjelaskan tentang bentuk-bentuk partisipasi warga negara sebagai berikut:

"Adipura lingkupnya adalah Kota. Jadi, Kota dalam pengelolaanya memiliki dua tugas utama yakni pengelolahan sampah dan keasrian lingkungan. Pengolahan 
sampah yang dilakukan berupa pemilahan sampah. Sampah plastik selanjutnya diolah menjadi kerajinan sedangkan sampah organik dijadikan kompos. Pengolahan ini diberlakukan baik Pemukiman, Sekolah, Pasar, Terminal, Perkantoran, Jalan, Stasiun Kereta Api, maupun fasilitas umum. LH hanya sebagai koordinator pengelolaan dan mendorong pihak dinas-dinas terkait untuk bersama-sama mengelola lingkungan seperti Dinas PKD, Taman Kota, UPTD atau Dinas Pendidikan, Camat, Lurah, Bagian Pemeritahan, PJKA. Adipura menjadi tanggungjawab semua warga kota, jadi semua elemen yang ada harus dipersiapkan. Tentunya hal ini perlu adanya dorongan dari masyarakat agar setiap hari kondisi lingkungannya tetap bersih. LH bertugas mensosialisasikan, mengajak masyarakat terus melakukan kebersihan itu tugasnya. Adapun bentuk pengelolaannya bisa bermacam-macam, ada yang 3R yang merupakan program lama kementrian, adanya bank sampah yakni dengan memilih sampah kering kemudian dijual serta dananya dapat digunakan untuk pengelolahan lingkungan.”.

Bentuk partisipasi warga Negara dalam lingkungan hidup pada tingkat masyarakat berawal dari adanya Adipura dengan tujuan melakukan pemberdayaan masyarakat yang dimulai dari kebersihan lingkungan seperti pengelolaan sampah dalam bentuk Bank sampah.

Pendapat, lainnya disampaikan oleh A3 Staff Dinas Kehutanan Kabupaten Blitar bahwa bentuk partisipasi warga dalam pelestarian lingkungan hidup dituturkan sebagai berikut;

"Bentuk partisipasi dalam LH dalam bentuk "gerakan penghijauan lingkungan" yang konsern terhadap penghijauan lingkungan. Ada juga "gerakan penanaman" yang memfokuskan kegiatannya pada gerakan penanaman lahan kritis.
Untuk tahun ini, rencananya akan dilakukan penanaman serentak di seluruh Indonesia pada bulan Desember."

\section{KESIMPULAN}

a. Bentuk-bentuk partisipasi Warga Negara dalam pelestarian lingkungan hidup dilakukan melalui kegiatan-kegiatan masyarakat dan dunia pendidikan (monolitik dan integratif).

b. Kompetensi kewarganegaraan diperlukan agar warga Negara dapat berpartisipasi dalam lingkungan hidup dengan pembekalan dimensi/domain knowledge, skill dan disposition tentang lingkungan hidup melalui berbagai kegiatan di masyarakat dan pendidikan.

c. Bentuk penguatan partisipasi warga Negara dalam Pelestarian Lingkungan Hidup dilakukan melalui kegiatan pelatihan bagi masyarakat, sekolah, sosialisasi tentang lingkungan hidup, penguatan peran organisasi-organisasi relawan lingkungan hidup, serta KMDM di SD dan sekolah SMP.

d. Penguatan partisipasi warga negara tentang pelestarian lingkungan hidup berdasar konsep green moral dalam pembangunan berkelanjutan mengacu pada nilai-nilai Pancasila untuk sopan santun, bersih, mencintai lingkungan, dan menjaga lingkungan hidup untuk tercapai kepekaan terhadap lingkungan hidup melalui adaptasi dari hidup modern dengan mempertahankan dan melindungi lingkungan hidup, tujuan yang jelas dari pelestarian lingkungan hidup, integrasi dari nilai-nilai Pancasila dan lingkungan dalam integrasi berbagai macam kegiatan, serta adanya latency dalam sistem yang dibuat masyarakat dan pemerintah. 


\section{DAFTAR PUSTAKA}

Budimansyah, D. dan Suryadi, K. (2008), PKn dan Masyarakat Multikultural, Bandung, Prodi PKn, Sekolah Pascasarjana, UPI.

Budimansyah, D. (2006), Pendidikan Nilai Moral dalam Dimensi Pendidikan Kewarganegaraan, Bandung, Lab. PKn-FPIPS, UPI.

Budimansayah, D. dan Komalasari, K. (2011), Pendidikan Karakter: Nilai inti bagi upaya Pembinaan Kepribadian Bangsa, Bandung, Widya Aksara Press

Bogdan, R.C. \& Biklen, S.K (1982), Qualitative Research for Education: An Introduktion to theory and Methods, Boston, Allyn and Bacon Inc.

Box, Richard C, (1998), Citizen Governance: Leading American Comnities into the 21 Century, Thousand Oaks: Sage Publikation.

Burke, J dan Ewan, J, (1999), Sonoran Preserve Master Plan for the Phoenix Sonoran Desert, City of Phoenix Parx Recreation dan Library Departement.

Gaventa, J. (2002). Introduction; Exploring Citizenship, Participation and Accountability, Bulletin IDS Vol.33 No. 2,2002, Brighton: Institute of Development Studies, University of Sussex.

Henry, N. (2004). Public Administration and Public Affairs, New Jersey: Pearson Prentice Hall.

Islamy, M.I. 2004. "Membangun Masyarakat Partisipatif” artikel dalam Jurnal Administrasi Publik, Vol.IV No. 2 Maret-Agustus 2004.

Keraf, A. S. (2006) Etika Lingkungan, Jakarta: Penerbit Buku Kompas

Muluk, K. (2007). Menggugat Partisipasi Publik dalam Pemerintahan Daerah, Sebuah Kajian dengan Pendekatan Berfikir Sistem. Malang: Lembaga Penerbitan dan Dokumentasi FIA Unibraw dan Bayumedia.

Nelson, N. dan Susan W. 1995. Power and Participatory Development, Theory and Practice, London: Intermediate Technology Publikation.

Pretty, J.(1995). Regenerative Agriculture: Policies and Practice for Sustainability and Selfeliance.London, Earthscan.

Sapriya dan Winataputra, U. (2004), Pendidikan Kewarganegaraan: Model Pengembangan Materi dan Pembelajaran, Bandung, Laboratorium PKn-FPIPS, UPI

Syahyuti. (2005). Partisipasi. Pusat Analisis Sosial Ekonomi dan Kebijakan Pertanian. Bogor, IPB

Tikson. D. T., (2009). Partisipasi Masyarakat Dalam Manajemen Perkotaan http://id.shvoong.com/sosialsciences/political-sciance/1883653-partisipasi-masyarakat-dalam-manajemen-perkotaan/.Diakses $\quad 20$ Juni 2009.

Thoha, M. (2005), Dimensi-Dimensi Prima Ilmu Administrasi Negara, Jakarta: Raja Grafindo Perkasa.

Yunus, H.S., (2005). Manajemen Kota Perspektif Spasial. Yogyakarta:Pustaka Pelajar. 